\title{
学界情報
}

\section{International Battery Association 2018 (IBA 2018) 報告}

\section{橋上 聖〔関西電力(株)〕}

\section{1. はじめに}

2018 年 3 月 11 日〜 16 日に韓国済州島で International Battery Association（IBA 2018）が開催された。IBAはリ チウムイオン電池 (LIB) などの二次電池をテーマとして毎 年開催される国際会議であり，今回の参加者は 19 力国 350 名程度（アジア $75 \%$ ，ヨーロッパ $15 \%$ ，米国 $8 \%$ ，その他 $2 \%)$ であった。済州島は韓国でも有数の観光都市であるが, 最近では二次電池や電気自動車と連携して積極的に再生可 能エネルギーの導入を進める地としても知られる。

\section{2. 会議の概要}

口頭発表（68 件）は全て招待講演であり, 図 1 で示す会 場で行われた。世の中の LIB の高エネルギー密度化に向け た流れは, 現状の $150 \sim 200 \mathrm{Wh} \cdot \mathrm{kg}^{-1}$ からまずハイニッケル 正極とシリコン系負極を用いることで $300 \mathrm{Wh} \cdot \mathrm{kg}^{-1}$ を目指 し, 硫黄正極やリチウム金属負極でさらなる向上を狙いつ つ, 究極的には LIB の原理に依らない多価イオン電池やリ チウム空気電池などで $500 \mathrm{Wh} \cdot \mathrm{kg}^{-1}$ を達成するというもの である。IBA2018 では二次電池材料に関する報告が大半を 占めた。分野別では正極材料に関する講演が最も多かった。 Pacific Northwest National Laboratory など多数の研究機 関から高容量ハイニッケル正極の高いサイクル特性が示さ れており，あらためて次世代正極材料の現実的な候補であ ることが窺い知れた。また，コバルトの供給リスクなどの 問題からコバルトフリーを呼びかける報告も複数見られた。

講演数が次に多かったのが負極材料である。主な講演は シリコン系やリチウム金属を用いることで大幅なエネルギ 一密度の向上を目指すものであった。シリコン系はリチウ ム合金化や脱合金化の際の膨張収縮, リチウム金属はデン ドライト析出による短絡が課題である。負極材料の表面修 飾や集電体との親和性改善など様々な検討がなされている が，本質的な課題解決には至っていない印象である。

電解質については固体系や液系に関する報告が見られた。 全固体電池は既存の製造ラインにのせることが困難であり 実用化の大きな障壁となっているが，2016 年に硫化物系に おいて $25 \mathrm{mS} \cdot \mathrm{cm}^{-1}$ という従来の液系を凌駕するイオン伝導 度が報告されたこともあって本会での関心は高く, 多くの 報告やそれに対する質疑応答があった。液系は濃厚系電解 液に関する報告が複数見られた。正極を高容量化するには 従来よりも高電位まで充電する必要があるため, 既存電解 液を濃厚化することによる耐久性の向上は次世代 LIB を開 発する上で重要な役割を果たすと考えられる。また，一般 に電解液は可燃性であるが，濃厚化した電解液を消火剂と して機能させた報告があり, 電解液を火に吹きかけること

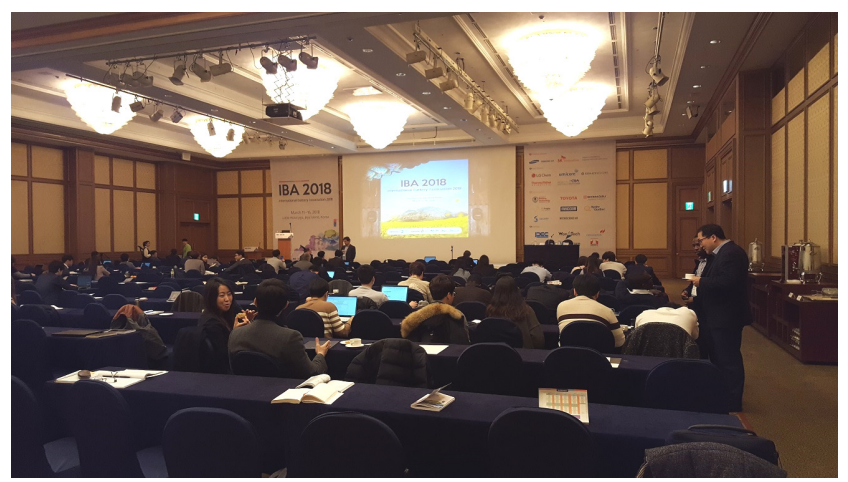

図 1 講演会場

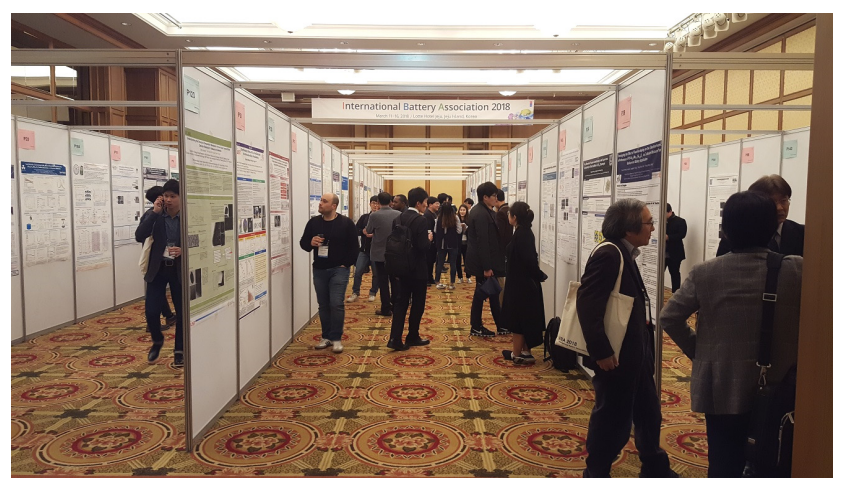

図 2 ポスターセッションの様子

で再発火できなくなる動画が印象的であった。

会場で特に盛り上がったのが Wearable で Printable な電 池を開発している Ulsan National Institute of Science and Technology の講演であった。電源が印刷された綿の $\mathrm{T}$ シャ ツが, 洗濯しても畳んでも作動することを示す動画は, 会 場中の注目を集めていた。

筆者が発表したポスターセッション（159 件）は二, 四日 目に開催され, 活発な議論を行うことが出来た (図 2 )。韓国 人は学生でも英語力が高く, 筆者への良い刺激になった。

\section{3. おわりに}

太陽光や風力等の再生可能エネルギーの大量導入が見込 まれる中, 電源の不安定性を吸収する方策あるいは新たな 価值を提供するデバイスとして, 電力系統への二次電池導 入が検討されている。二次電池の安全な運用を実現するた めには電池システムの評価に加えて材料レベルでの評価を 適正に行うことが求められる。今後も本学会に積極的に参 加して, 部材の充放電サイクル特性や出力特性等の電気化 学的な知見を蓄積する必要があると感じた。

(2018 年 6 月 8 日受付) 